\title{
Om te gee: 'n Godsdiens- en sendingwetenskaplike perspektief
}

Author:
Jaco Beyers ${ }^{1}$
Affiliation:
'Department of Science of
Religion and Missiology,
University of Pretoria,
South Africa
Correspondence to:
Jaco Beyers
Email:
jaco.beyers@up.ac.za
Postal address:
PO Box 14125 Lyttelton,
Centurion 0140, South Africa
Dates:
Received: 27 July 2012
Accepted: 24 July 2012
Published: 22 Oct. 2012
How to cite this article:
Beyers, J., 2012, 'Om te
gee: 'n Godsdiens- en
Sendingwetenskaplike
perspektief', HTS Teologiese
Studies/Theological Studies
$68(1)$, Art. \#1289, 7 pages.
http://dx.doi.org/10.4102/
hts.v68i1.1289

(C) 2012. The Authors. Licensee: AOSIS OpenJournals. This work is licensed under the Creative Commons Attribution License.
To give: A science of religion and missiological perspective. Human nature has been depicted as being utilitarian. This means that man considers all social action in terms of an optimalisation of privilege for the self. Marcel Mauss challenged this theory by investigating the possibility of human nature as being anti-utilitarian. Man does not give in order to receive. Human social action is not necessarily motivated by what man stands to gain. The diaconate of the church can be seen as the social action of giving. There is a close connection between the diaconate and the apostolate as actions of giving by the church. This article wants to determine whether these actions by the church are utilitarian in nature. Sundermeier's use of the concept of convivence is used to illustrate how the church acts in an anti-utilitarian fashion when engaging in the diaconate and the apostolate. The social theory of Mauss, the missionary perspective of Sundermeier and the theology on the diaconate by Moltmann are brought into conversation with one another in order to illustrate the anti-utilitarian activities of the church in society.

\section{Inleiding}

Die sosioloog Marcel Mauss het in die begin van die twintigste eeu navorsing gedoen om vas te stel wat die logiese redes agter die optrede en handelinge van mense in die samelewing is. ' $n$ Mens handel nie onbewustelik nie. Daar moet 'n rede wees waarom 'n mens iets doen.

\section{'The Gift'}

Mauss se navorsing moet teen die agtergrond van die sosiologiese teorie van utilitarisme verstaan word. Utilitarisme is volgens Caillé (n.d.:3) die leer dat die mens as individu net geïnteresseerd is in dit wat vir eie geluk en plesier waarde het. Die individu probeer om by wyse van rasionele denke die geluk en plesier in alle geleenthede te optimaliseer en alle ongemak en pyn te minimaliseer. Utilitarisme staan binne die sosiologie as die 'ekonomiese model vir die menswetenskappe' bekend. Die moderne sosiologie werk met die teorie van die mens as homo oeconomicus. Dit wil sê, alle menslike aksies in die samelewing kan tot instrumentele rasionalisme gereduseer word. Die mens tree nie net op nie, handel nie maar net nie, doen nie sommer maar net dinge nie. Elke handeling word deur 'n fyn rasionele berekeningsproses voorafgegaan. Die mens tree berekend op. Tog bestaan daar ook ander kategorieë waarbinne die menslike karakter omskryf kan word (bv. homo religiosus, homo ritualis, homo simbolicum).

Die utilitarisme veronderstel dat die mens dinge om 'n rede doen om iets te vermag. Anders gestel: Die mens bereken die uitkoms van sy of haar aksies. Die middel wat die mens gebruik, is op die realisering van 'n spesifieke doel gerig. Die mens is berekend - ons redeneer oor, beplan ons aksies. Ons optrede is nie klinies en masjienmatig nie. Ons dink wat ons doen. Soms doen ons onbewustelik mee, maar dan is menslike handeling die onbewuste navolging van ' $n$ tradisie wat op 'n spesifieke, berekende doel gerig is. Die mens is ekonomies ingestel - die mens bereken die koste van enige optrede. Watter verskuilde wins skuil daar vir my in my optrede? Hoe kan ek met die minste moeite my kanse op maksimale voordeel verhoog?

Met hierdie sosiologies-teoretiese onderbou (naamlik die utilitarisme) ondersoek Mauss vervolgens die redes waarom die mens gee. Mauss probeer om in navolging van Durkheim se antiutilitaristiese teorie te bewys dat daar ander redes as ekonomiese redes agter menslike handelinge mag skuil. Hy ondersoek die verskynsel van die gawe of geskenk en hoe dit by primale kulture funksioneer om vas te stel of die mens steeds in die moderne era volgens dieselfde oerbeginsels gee. Wat is die logika agter die aksie van gee?

Mauss doen in hierdie verband navorsing onder gemeenskappe wat op eilande in die Stille Oseaan en landelike gemeenskappe in Australië woonagtig is, asook die stamkulture in Noord-Amerika. Hy kies hierdie gemeenskappe juis omdat hierdie gemeenskappe volgens 
die teorie van Durkheim blyk die gewoontes en gebruike van die primitiefste oergemeenskappe te vertoon. Hierdie gemeenskappe is tradisionele stamkulture wat oor eeue heen weinig blootstelling aan ander kulture en invloede van buite gehad het. Hoe hierdie gemeenskappe leef, meen Mauss, is hoe ons kan aanneem alle mense in oergemeenskappe hulle gedra het. Hulle gewoontes en gebruike demonstreer hoe die vroegste mens oor die lewe gedink het en met mekaar in hegte samelewingstrukture saamgeleef het. Hierdie gemeenskappe demonstreer trekke van die ware (oorspronklike) menslike natuur.

Mauss ondersoek een spesifieke element in hierdie tradisionele gemeenskappe, naamlik die gebruik om 'n geskenk vir ander te gee. Mauss se gewaarwordinge en bevindinge vind neerslag in die boek The gift: The form and reason for exchange in archaic societies (1921) wat in 1990 in Engels vertaal is en so wyer toeganklikheid verkry het. Hierdie boek is egter deel van 'n groter projek deur Durkheim en sy studente.

Durkheim se nadenke oor sosiologiese beginsels ontstaan binne 'n bepaalde konteks. In Frankryk was die gemeenskap gedurende die einde van negentiende en die begin van die twintigste eeu besig om weens die industrialisering van Europa te verander. 'n Verbruikersmentaliteit begin al meer die samelewingspatrone bepaal. Koop en verkoop en besit word eienskappe wat die samelewing as suksesvol kenmerk. Menslike ingesteldheid teenoor besit en sosiale interaksie verander. Mense soek selde na dit wat voordelig vir ander sal wees. Die veranderende gemeenskap in 'n geïndustrialiseerde Europa van die twintigste eeu maak dat die rede waarom mense vir ander gee, verander. Met The Gift dui Mauss aan waar die wortels van moderne ekonomiese beginsels lê.

Om vir ander iets te gee, klink na normale praktyk en amper vanselfsprekend vanuit 'n Christelike etiese hoek. Mauss dui egter aan dat dit wat vandag vir ons vanselfsprekend en spontaan mag lyk van die vroegste tye af 'n gemeenskap en individue se optrede volgens streng en ongeskrewe reëls bepaal het.

Binne primale en argaïese gemeenskappe was om te gee 'n voorskrif, 'n reël, 'n wetmatigheid. In der waarheid het die gawe binne 'n drieledige verpligting gefunksioneer: om te gee, om te ontvang en om met 'n gawe te beantwoord (Mauss 1990:39). Die gee-beginsel was 'n resiprokale, kousale en respekvolle aksie wat van alle mense verwag is.

\section{Resiprokaal}

Mauss se bevindinge dui aan dat die basiese beginsel wat die aksie van gee by primitiewe gemeenskappe gereguleer het, resiprokalitiet was. Binne moderne politieke en ekonomiese denke oor sosiale aksie funksioneer resiprokaliteit steeds as basiese beginsel (Caillé n.d.:1). Resiprokaliteit verwys na die wiskundige beginsel dat, om ekwilibrium in 'n wiskundige verhouding te handhaaf, dit wat aan die een kant van die verhouding gebeur ook aan die anderkant van die konstruksie moet plaasvind. Binne 'n sosiologiese konteks beteken dit dat waar 'n geskenk van een party aan 'n ander oorhandig word, die verwagting bestaan dat ' $n$ geskenk in ruil teruggegee sal word. Hierdie verwagting bestaan by albei deelnemers wat by die sosiale interaksie betrokke is. Die verdere verwagting is dat die geskenk wat in ruil aangebied word van soortgelyke waarde moet wees as die geskenk wat ontvang is.

'n Geskenk mag nie geweier word nie. Dit is 'n teken van vyandigheid wanneer 'n geskenk geweier word of nie met 'n teen-geskenk beantwoord word nie (Mauss 1990:13, 41). Om 'n geskenk van mindere waarde te gee as die geskenk wat ontvang is, is ewe beledigend.

Die konsep van die geskenk is nie op die konsepte aalmoese, barmhartigheid of toegifte van toepassing nie (Caillé n.d.:5). Geskenke word eerder as simbole beskou (Caillé n.d.:5). Mauss het bevind dat die geskenke wat uitgeruil word 'n geestelike dimensie besit. Die geskenk is 'n uitdrukking van die gees van die gewer. Die siel van die gewer is met die geskenk vermeng (Mauss 1990:20). Deur te gee, gee die gewer iets van hom of haarself. Die ontvanger ontvang dan 'n geskenk vanuit die hart van die gewer en antwoord op soortgelyke wyse. Daardeur word die lewe van die gewer en ontvanger, die ontvanger en die gewer onlosmaaklik met mekaar verbind (Mauss 1990:20).

Ten grondslag van die uitruil van geskenke lê die struktuur van eer en skande. Deur te gee, poneer die gewer die eie status en eer in die samelewing (Caillé n.d.:5). Deur nie te gee nie, verloor die nie-gewer status en eer in die gemeenskap. Die gee-aksie word egter nie net verwag van dié wat baie besit nie. Almal gee, wat daar ook al mag wees om te gee. Selfs die oorvloed van die oes of oorvloed van die jagtog kwalifiseer as geleentheid om die mede-gemeenskapslede te nooi om te deel in wat beskikbaar is, hoe gering ook al. Deur nie te nooi nie, kom die gewer in die skande. Caillé (n.d.:5) wys daarop dat die gevaar dat 'n individu self te kort sou kom deur vir ander te gee juis 'n groter geleentheid vir eer inhou.

Geskenke is bloot simbolies van aard. Die geskenk mag dalk geen utilitaristiese waarde besit nie (in sommige kulture het Mauss [1990:23] gevind dat mense skulpe met geen gebruikswaarde, slegs estetiese waarde, uitruil). Die gewilligheid om geskenke uit te ruil, word simbool van die sosiale verhouding waaraan erkenning gegee word (Caillé n.d.:5). Die veronderstelling is 'n egalitêre gemeenskap waar almal as besitters van iets beskou word. Almal het iets om te gee. Deur te gee erken mense die bande tussen mekaar. Deur nie te gee nie kom skande oor die nie-gewer, en word verhoudinge verbreek.

\section{Kousaliteit}

Mauss (1990:22) identifiseer 'n direkte verband tussen gee en ontvang. Die een sluit die ander nie uit nie, maar die een volg die ander op. Daar bestaan dus 'n logiese volgorde: Ek gee, jy gee (do ut des; Mauss 1990:ix). Die kousaliteitsbeginsel word soms in stamkulture op godsdienstige gebruike toegepas. Die 
offers wat aan gode gegee word, word met die verwagting gegee dat die gode 'n teenprestasie sal lewer omdat daar vir hulle gegee is (Mauss 1990:ix). Dieselfde kousaliteitsbeginsel word deur Mauss in primale kulture waargeneem.

Die verpligting is om te gee, te ontvang en weer te gee (Mauss 1990:43). 'n Onsigbare, innerlike dryfkrag dryf hierdie verpligting (Mauss 1990:43). Die verhoudinge wat tot stand kom, word deur die herhaaldelike gee van geskenke in stand gehou. Dit kan outomaties verwag word: Iemand vir wie ek iets gegee het, staan onder die verpligting om weer vir my te gee. Deur nie te gee nie, verbrokkel die verhoudinge en verloor die nie-gewer eer en aansien in die gemeenskap.

Hierdie beginsel wat Mauss geïdentifiseer het, bevestig die anti-utilitaristiese beginsel in sosiologiese terme. Die sosiale gee-aksie het geen rasionele, selfsugtige gemotiveerdheid nie. Hoogstens kan die verpligting om te gee, te ontvang en in ruil terug te gee vanuit 'n logika van simpatie verklaar word (Caillé n.d.:6). Natuurlik ervaar elke individu 'n mate van voordeel, plesier en geluk in die verhouding van gee en ontvang. Dit kom egter teen 'n prys. Ek kan slegs ontvang, as ek gee. Binne hierdie paradoks gaan selfbelang op in onselfsugtigheid (Caillé n.d.:6). Binne die verpligting om te gee, bestaan die potensiaal van vryheid (Caillé n.d.:6). Die individu word vry sodra die individu gee.

\section{Eer en skande}

Binne die konstruksie van eer en skande funksioneer die verpligting om te gee as die middel waardeur die mens eer ontvang. Om te ontvang, is dus nie 'n soeke na rykdom nie, maar die begeerte om erkenning in die gemeenskap te geniet (Caillé n.d.:7). Mauss wou juis met sy ondersoek na die funksionering van die gawe wys dat die mens antiutilitaristies funksioneer. Die mens soek nie in alle aksies na dit wat waarde, plesier en geluk bring nie, maar die mens het in der waarheid ' $n$ diep verlange om erken te word en as 'n gewer gereken te word (Caillé n.d.:7). Juis deur te gee, ontvang die individu eer en aansien in die gemeenskap. Die teendeel is natuurlik dat sou iemand bekend staan as iemand wat nie gee nie, dit skande en oneer oor die persoon sou bring.

Eer word dus die kommoditeit waarom meegeding word. Eer kan net ontvang word wanneer ander dit toeken. Die individu is dus aan die erkenning van die gemeenskap uitgelewer. Die individu moet dus bly gee om eer en aansien in die gemeenskap te bly behou.

\section{Diakonaat: Die kerklike konsep van gee/deel/barmhartigheid}

Diakonaat verwys tweeledig na enersyds die werk wat die kerk as instituut in die wêreld doen om nood in die samelewing te verlig en andersyds na die werk om lidmate van die kerk toe te rus om as gemeentelede nood in die wêreld aan te spreek (Noordegraaf 1991:158). Die kerk is op die nood in die samelewing gerig, of dit nou slagoffers van leed, nood of geweld is of enige iets anders (Noordegraaf 1991:158). Die twee lyne van die kerk se gerigtheid op die nood in die samelewing is teologies verder uitgewerk deur Hoedemaker, Haitjema en Van Ruler wat klem plaas op die kerk se roeping as instituut om saam en naas ander institute die samelewing van hulp te bedien. Aan die ander kant het Kuyper se teologie die kerk se funksionering as organisme beklemtoon waar die kerk lidmate vir hulle spontane dienswerk in die samelewing toerus. Volgens laasgenoemde model handel lidmate dus op eie verantwoordelikheid in die samelewing (Noordegraaf 1991:160).

Die kerk se fokus op die nood in die samelewing (hetsy as instituut of organisme) gaan hand aan hand met die getuienis van heil en verlossing wat God deur Christus aan die wêreld bied (Noordegraaf 1991:162). Om na die stand van welsyn te vra, het ook te make met die vraag na versoening met God (Noordegraaf 1991:180). In hierdie opsig bestaan daar 'n noue band tussen die diakonaat en die apostolaat. Van Ruler het lank reeds die noue verband tussen diakonaat en apostolaat beklemtoon (Noordegraaf 1991:162). Die band is vir Van Ruler onlosmaaklik sodat die diakonie nie sonder kennis van die lewende God kan bestaan nie.

Diakonaat as die aanspreek van die nood van die mens in die samelewing het nie 'n humanistiese vertrekpunt ten grondslag nie. Die evangelie bly die vertrekpunt en motivering vir die diakonaat (Noordegraaf 1991:162). Die evangelie as begronding vir die diakonaat verhinder dat die kerk ontaard in 'n aksiegroep wat op maatskaplike nood gerig is (Noordegraaf 1991:163). Die diakonaat is nie die uitleef van 'n (humanistiese) lewensbeskouing gegrond op etiese norme en waardes nie, maar 'n handeling uit die oortuiging van die liefde van Christus wat die kerk tot diens aan die samelewing dryf (Noordegraaf 1991:163).

Oor die oorsprong van die nood van die mens in die samelewing kom Moltmann baie naby daaraan om die utilitaristiese, geïndustrialiseerde, kapitalistiese samelewing die skuld vir maatskaplike probleme te gee (Moltmann 1984:16-18). Die geïndustrialiseerde gemeenskap dra daartoe by om die mens van ondersteuningsgroepe soos die familie, die stamverband of die klein-dorp gemeenskap te isoleer (Moltmann 1984:17). Die diakonaat is nie die poging om die sosiale bestel te verander nie, maar die diakonaat word die handel van die kerk in die gemeenskap vanuit die liefde van God (Moltmann 1984:19).

Die diakonaat van die kerk is vir Moltmann (1984:19) in die eskatologie begrond. Deur die sterwe en opstanding van Jesus is die Ryk van God op aarde gevestig. Deur die uitstorting van die Heilige Gees word die Ryk telkens 'n nuwe realiteit in die gehoorsame handel van gelowiges. Die koninkryk van God wat met die koms van Christus aangebreek het, sal eers met die wederkoms vervolmaak word. Tot dan oorwin die goeie die bose slegs in soverre die kerk die liefde leef (Moltmann 1984:19). Die diakonaat word dus die navolging van die gekruisigde Heer wat die Koninkryk van God kom vestig het (Moltmann 1984:23). 
Binne die horison van die koninkryk word die diakonaat omvattend. Die diakonaat kan nie in organe geïnstitusionaliseer word nie. 'n Allesomvattende diakonaat bestaan uit alle helende handelinge wat die mens sonder heil met God en medemens versoen (Moltmann 1984:28). Vir Moltmann mag die diakonaat nie na net sommige gelowiges gedelegeer word nie. Die amp van die priesterskap van gelowiges is ook op die diakonaat van toepassing (Moltmann 1984:73). Elke gelowige in die gemeente moet die verantwoordelikheid opneem om liefde te leef. In hierdie opsig geskied die diakonaat in en deur die helende gemeenskap (Moltmann 1984:38): gemeenskap tussen gelowiges onderling asook uitdrukking van gemeenskap met die mens in nood. Hierdie onderlinge gemeenskap herinner aan Sundermeier se konsep van konvivenz (kyk onder) waar die gelowige in noue verbintenis met die onbekeerde mens leef.

Vir Moltmann is daar geen waarde of voordeel vir die kerk daarin om diakonaat te beoefen nie. Die diakonaat vind plaas in gehoorsaamheid aan die opdrag om lief te hê, asook in 'n gedrewenheid deur die liefde van God (Moltmann 1984:19). Die opdrag om die naaste lief te hê, is juis op die ander gerig en nie op die self nie (Moltmann 1984:54). Die kerk se liefde is dus selflose liefde. Die gelowige of kerk se handel in liefde geskied nie met die verwagting van resiprokale teenprestasie nie.

As mens geskape na die beeld van God het die mens die opdrag om die beeltenis van die liefde van God uit te leef (Moltmann 1984:67). Op hierdie wyse reflekteer die gelowige God se eer deur liefdevolle handel in die wêreld (Moltmann 1984:67). Mauss beskryf die eer wat met die gee-aksie gepaard gaan. In hierdie opsig kom eer ook na aanleiding van die handel deur die diakonie ter sprake. Die eer kom egter nie die kerk of gelowige toe nie, maar God.

Vir Noordegraaf (1991:209) funksioneer die beginsel van wederkerigheid (lees resiprokaliteit) uniek in 'n situasie waar die diakonaat vanuit die oorvloed van die gewer (normaalweg die ryk Westerse kerk) die gebrek van die ontvanger (normaalweg die arm Derde-Wêreldse kerk) aanspreek. In hierdie situasie geld primêr die beginsel van gelykheid (Noordegraaf 1991:209). Die diakonaat is gesteld op liefde leef. Alle situasies waar die meerderwaardigheid van een party bo die van 'n ander party beklemtoon word, moet vermy word. Ongelyke vennote bring ' $n$ wanbalans in die verhouding en dra nie tot die heling van die gemeenskap by nie.

Om deur die handeling van die diakonaat aan die gemeenskap te gee (wat ook al nodig mag wees om heling in die gemeenskap te bring), vind nie met 'n resiprokale verwagting by die kerk plaas nie. In hierdie hoedanigheid is die kerk anti-utilitaristies ingestel wanneer die kerk teen die agtergrond van die diakonaat gee.

\section{Apostolaat: Die kerklike aksie van verkondiging of mededeling van die evangelie}

Die kerk se verstaan van die missio Dei (Bosch 2011:10, 398) laat die kerk met die bewussyn van deel wees van die koninkryk van God; besig om die opdrag om die evangelie van Jesus Christus saam met ander met die wêreld te deel (Matt 28:19; Hand 1:8). Die kerk as gestuurde het iets om aan die wêreld te gee: die boodskap van hoop en vergifnis deur geloof in Jesus Christus. Hierdie aktiwiteit om gestuurde in die wêreld te wees, is meer as 'n opsie. Die totale Christelike lewenswyse is dié van 'n missionêre bestaan (Bosch 2011:10). Die doel van hierdie aktiwiteit van die kerk is tradisioneel omskryf (vergelyk Voetius se drieledige uiteensetting van die doel van sending) as om onbekeerdes tot bekering te lei, die eer van God te bevorder en om die kerk te plant (Bosch 2011:9).

Sundermeier stel ' $n$ bepaalde model voor waarvolgens hierdie gestuur wees van die kerk in die wêreld gestalte kan vind. Sundermeier se model probeer om 'n brug tussen die diakonaat (praktyk van gee) en die apostolaat (praktyk om die evangelie te deel) te slaan. Om die brug tussen die diakonaat en die apostolaat aan te dui, gebruik Sundermeier die Latyns-Amerikaanse teologiese term konvivenz (afgelei van die Latyn con-vivere) wat beteken 'om saam te leef' (Sundermeier 1995:44). Konvivenz verwys na meer as om in dialoog met ander te wees en meer as blote ontmoeting met ander; dit verwys na die deel in lewenservaring (Sundermeier 1995:44). Die beginsels van toepassing in konvivenz word ge-eggo deur Noordegraaf (1991:209) se aandrang op gelykheid tussen partye waar die kerk in verhouding met ander gemeenskappe en kerke staan. Hierdie wederkerige gelykheid, wat Noordegraaf voorstel, stem met Sundermeier se konsep van konvivenz ooreen.

Die bruikbaarheid van die konsep konvivenz lê juis daarin, sê Sundermeier (1995:45), dat die konsep teorie en praktyk verbind, dat teorie en praktyk met die term verwys na dit wat mense in gemeen het, naamlik die lewe. Die mens as sosiale wese deel in die lewe as gemene deler.

Die konsep konvivenz is 'n sosiologiese beginsel waarvan die oorsprong in die beskrywing van die interaksie tussen stamkulture lê. Konvivenz is in wese resiprokaal. In hierdie opsig vind dit aansluiting by Mauss se verstaan van die aksie van gee as resiprokale aksie. Aangesien konvivenz verwys na die gemeenskap wat daar tussen individue bestaan, is die klem juis op die uitruil wat tussen partye plaasvind. Hierdie uitruil kan verskillende vorme aanneem.

\section{Hulpgemeenskap}

Konvivenz gee uitdrukking aan die beginsel van ondersteuning en versorging wat in nou verweefde gemeenskappe plaasvind (Sundermeier 1995:46). Dit beskryf die hulp wat in 
situasies van nood te verleen is - sosiale nood, welsynsnood en emosionele nood. Bosch beskryf hierdie gesindheid as die riglyn vir die missionêre wat die Lukas-evangelie aan die kerk voorstel; 'n gesindheid van 'solidariteit met die armes' (Bosch 2011:99). In die opsig beskryf konvivenz die aksie wanneer gelowiges vir ander mense gee wat nodig is om te oorleef.

Deur te gee, illustreer die kerk die eensgesindheid en onderlinge verbondenheid tussen die kerk en gemeenskap. Onder die konsep van die hulpgemeenskap sou die kerk waarskynlik die diakonale aktiwiteite van die kerk in die wêreld verstaan. Noordegraaf (1991:209) verwys na die tendens waar ryk Westerse kerke vanuit die diakonie arm Derde-Wêreldse kerke bystaan. Om hulp te verleen, kan wyd interpreteer word en kan op vele terreine ter sprake wees. Sundermeier bedoel juis dat die kerk in 'n missionêre konteks moet gee wat ook al nodig in die spesifieke konteks mag wees (bv. kos, klere, medisyne, rekenaars, boeke en tente).

Konvivenz, het ons reeds aangedui, lê binne 'n resiprokale dimensie. Noordegraaf (1991:210) pleit vir die behoud van onafhanklikheid van die ontvanger (ontvangende kerk) om die reg te behou hoe om die middele wat ontvang is, aan te wend. Die diakonie vind volgens Noordegraaf (1991:210) binne ' $n$ vertrouensdimensie plaas. Die ontvanger moet vertrou word om dit wat ontvang is, korrek aan te wend.

Resiprokaliteit veronderstel dat daar 'n uitruil van geskenke sal plaasvind. Tussen twee gemeenskappe wat in 'n wanbalans van besit leef, is dit moeilik om van albei geskenke in gelyke waarde te verwag (vergelyk Noordegraaf 1991:209). Beteken dit dat die kerk wat oor middele beskik sondermeer moet gee waar daar nood is sonder om iets in ruil te verwag?

Die gee-aksie is nie 'n besigheidstransaksie waaruit die kerk iets kan baat nie. Tog sou die ontvanger die geleentheid gegun moet word om te ontvang en 'n geskenk terug aan te bied, hoe gering ook al. Dit is gebaseer op Mauss se veronderstelling dat gee, ontvang en om terug te gee sosiale interaksie kenmerk. Die ontvanger kry daarmee die geleentheid om met trots nie net as ontvanger bekend te staan nie, maar ook die eervolle naam van gewer te bekom.

\section{Leergemeenskap}

Konvivenz veronderstel dat die basisgemeente 'n leergemeenskap is (Sundermeier 1995:47). Hierdie leeraktiwiteit kan formele onderrig insluit, van kennis van die ander kultuur tot lewenswysheid wat deur ervaring opgedoen is (Sundermeier 1995:47). Die basiese kennis sou tog veronderstel dat mekaar se taal aangeleer word sodat effektiewe kommunikasie plaasvind. Kennis van mekaar se kulture sal voorkom dat sosiale taboes oortree word. Kennis van geloofsoortuigings en wêreldbeskouings bring begrip vir mekaar se lewensuitkyk en -verwagtinge. Noordegraaf (1991:210) wys daarop dat die gewer ingestel moet wees op die vrae wat die ontvanger mag stel. Soms mag hierdie vraag na kennis ongemaklike vrae wees, gebaseer op pynlike ervaringe uit die verlede (bv. rassisme, kolonialisme, eksploitasie). Deur te luister, hoor die gewer die ware nood van die ontvanger.

Die kerk het tradisioneel die taak om ander binne hierdie raamwerk van onderrig van die evangelie te leer. Die oordrag van kennis het dan in 'n monoloogagtige gesprek ontaard, asof daar net by een van die gespreksgenote iets van waarde te leer is. Die kerk as boodskapdraer sien die ander gespreksgenoot as die onkundige wat nodig het om die evangelie te leer. Hierdie vorm van oordrag van geloofskennis het 'n rasionele uitkyk op geloof ten grondslag. Geloof is iets wat kognitief funksioneer. Daarom is geloofsoordrag inderdaad ' $n$ pedagogiese aktiwiteit. Dit kan egter nie by die rasionele eindig nie. Wat geglo word, moet geleef word. Daarom veronderstel geloofsoordrag ook 'n eksemplariese lewenswyse, sodat geloof inderdaad uit dade sigbaar kan word (Jak 2:18).

Konvivenz veronderstel resiprokale onderrig; albei partye het iets by die ander te leer. Die gesindheid wat by Christus was om Homself te verneder en te ontledig (Fil 2) sodat Hy sy solidariteit met die mens kon bewys, is by die kerk nodig (Sundermeier 1995:48). Hierdie waarlik saam-met mekaar en naas-mekaar lewe, veronderstel 'n nederige gesindheid teenoor die ander. Die een kultuur word nie as verhewe bo die ander beskou nie. Slegs in 'n leer-situasie waar daar saam met mekaar en van mekaar geleer word, kan die evangelie almal se lewe binnedring (Sundermeier 1995:48).

\section{Vieringsgemeenskap}

Die derde element waaruit konvivenz bestaan, is volgens Sundermeier (1995:49) die saamvier wat in 'n gemeenskap plaasvind. Die fees funksioneer in stammekulture as die onderlinge samebindende faktor. Feestelikheid is ' $n$ kommunale aktiwiteit wat wil omarm en insluit (Sundermeier 1995:49). Die fees onderbreek die alledaagse roetine momenteel om die lewe te verryk voordat die lewe weer kan voortgaan. Sundermeier (1995:49) identifiseer die fees as brug tussen kulture en godsdienste. Die fees verbind die bekende met die onbekende en verseker op hierdie wyse dat selfs die vreemdeling binne die gemeenskap plek kry. Noordegraaf (1991:210) wys daarop hoe die ontvanger die gewer in die gasvryheid kan laat deel, in oomblikke van vreugde en dankbaarheid ten spyte van armoede. Die kerk moet sensitief wees om in hierdie gevalle die rol van ontvanger in te neem en so te deel en die tweerigtingverkeer te bevorder (Noordegraaf 1991:210).

Die fees is 'n uitdrukking van identiteit. In 'n missionêre situasie kan die kerk die fees van die gemeenskap met nuwe inhoud vul. Hierdie kersteningsproses is deel van die geskiedenis van die Christendom. Gesamentlike aanbidding gee uitdrukking aan gesamentlike feesviering. Die feestelikheid kan 'n gesamentlike uitdrukking van dankbaarheid oor verlossing in Jesus Christus wees. Langs hierdie weg vind daar resiprokaal binne die deelgemeenskap 
viering plaas. Die fokus word dus verskuif weg van die kulture ter sprake na die transendente wat die fokuspunt van die viering word.

\section{Gevolgtrekking: Sundermeier in gesprek met Mauss en Moltmann}

Mauss identifiseer die wyse waarop die uitruil van geskenke binne primitiewe gemeenskappe funksioneer. Die wyse waarop die geskenk funksioneer, dien as illustrasie dat die mens van nature anti-utilitaristies is en ingestel is op dit wat vir die ander voordeel inhou. Die geskenk word die wyse waarop die mens eer in die samelewing akkumuleer, om sodoende as gewer bekend te staan. Die kerk tree ook as 'gewer' in die wêreld op. Die kerk as gestuurde van God deel die evangelieboodskap met die hele wêreld. Die diakonaat van die kerk is by uitstek die struktuur waardeur die kerk materieel aan die wêreld gee. Binne die spanningsveld van resiprokaliteit - gee as simbool en die eer-versus-skandekonstruksie - wil ons dan nou Sundermeier se missionêre konsep van konvivenz verstaan.

\section{Resiprokaliteit (anti-utilitaristies)}

Resiprokaliteit verwys na die beginsel van gee met die verwagting van ' $n$ wederkerige aksie. Mauss wys daarop dat resiprokaliteit die primitiewe stamkulture kenmerk. Die resiprokale teenreaksie het egter nie ten doel om die gewer te vergoed vir dit wat ontvang is nie. Mauss demonstreer hoe 'gee' as anti-utilitaristiese beginsel kan funksioneer. Die utiliteitsbeginsel probeer aantoon dat verbruik en besit 'n gemeenskap kenmerk. Alle sosiale interaksie word dan gemeet in terme van 'watter voordeel hou dit vir my in', om sodoende die hoogste voordeel vir die self te ontgin. Mauss demonstreer dat die utiliteitsbeginsel nie die oorspronklike menslike natuur kenmerk nie. Om te gee, is nie 'n selfsugtige aksie om te bepaal watter voordeel die gewer daaruit kan put nie.

Daar is min mense wat sal erken dat die kerk utilitaristies oor die kerk se aksie in die wêreld dink. Tog kan die kerk maklik skuldig wees aan gee met die verwagting dat daar 'n gelyke mate van teenprestasie moet wees. Sundermeier dui aan dat die kerk se missionêre bestaan in die wêreld juis deur die anti-utilitaristiese beginsel van resiprokalitiet gekenmerk moet word. Wanneer die kerk gee (ongeag of dit vanuit die diakonale of missionêre perspektief is), word onselfsugtig gegee met die openheid en bereidheid om te ontvang. Mauss identifiseer die eienskap om te ontvang as essensieel deel van sosiale interaksie.

Deur bereid te wees om te ontvang, erken die kerk die eie leegheid. Dit is egter nie 'n materiële of emosionele leegheid waarby die kerk sou baat deur te ontvang nie. Die erken van leegheid is 'n selfverstaan. Die kerk bestaan deur die genade van God. Op sigself het die kerk geen bestaansreg nie. God bring deur sy Gees die kerk tot stand en deur sy
Gees onderhou Hy die kerk. Die kerk besit nie die kerk en die skatte van die evangelie nie.

Die kerk is nie die geskenk aan die wêreld nie. Die kerk is slegs die draer van die boodskap van verlossing deur Jesus Christus. Christus is die geskenk aan die wêreld. Die kerk is slegs die draer van die geskenk. Heil en verlossing lê nie in die kerk opgesluit nie. Die kerk bemiddel nie die verlossing nie, maar is slegs getuie van die verlossing in Christus.

Wanneer die kerk dus aan die wêreld gee, verwag die kerk niks in ruil nie. Die kerk akkumuleer ook nie eer vir sigself nie. Die eer, wat op gee volg, kom God toe.

\section{Gee as eer}

Mauss dui aan hoe die gee-aksie binne die struktuur van eer en skande funksioneer. Deur te gee, ontvang die gewer aansien en eer binne die gemeenskap. Die resiprokale geskenk weeg dus nie in waarde op teenoor die eer wat die gewer in die oë van ander ontvang nie. Wanneer die kerk gee, kom daar wel ook eer te sprake.

Dit is egter nie die kerk aan wie die eer toekom nie. Die eer kom God toe. Die doel van sending is volgens Voetius drieledig: bekering van onbekeerdes, verheerliking en manifestering van die genade van God en planting van die kerk (Bosch 2011:262). Wanneer die kerk dus gee, ontvang God die eer.

Die kerk mag nie resiprokaal iets vir sigself verwag nie. Selfs op barmhartigheidshandelinge mag die kerk nie verwag dat ontvangers hulle bekeer of selfs as teken van dankbaarheid skielik begin kerk bywoon nie. Die kerk gee nie met die verwagting van 'n teenprestasie nie. Dit wat die kerk gee, is nie die besit van die kerk nie. Wat die kerk verniet ontvang het, moet die kerk verniet weggee, is die opdrag (Matt 10:8).

Wanneer die kerk onselfsugtig gee, is dit 'n uitdrukking van 'n God wat onvoorwaardelik gee. Die gee-aksie bring eer in die oë van die ontvanger. Die eer kom God toe. In hierdie opsig kan die kerk wat gee slegs simbolies in die wêreld optree. Wanneer die kerk gee, is dit 'n simboliese handeling.

\section{Gee as simbool}

Wanneer die kerk gee, is dit 'n simboliese handeling van selfontlediging en 'n heenwys na die ware Gewer wat alles vir die wêreld wil gee. Daar is reeds verwys na Caillé wat aandui hoe die gee-aksie simbool word.

Wanneer die kerk gee is daar geen resiprokale verwagting nie. Die gee-aksie is 'n simboliese uitdrukking van eenheid. Sundermeier dui aan dat wanneer die kerk gee daar wedersydse respek ontstaan aangesien die plig om te gee die status van die ontvanger erken. Die ontvanger word nie as sub-mens, afhanklik van die gewer gesien nie, maar as volwaardige gelyke vennoot van wie iets in ruil verwag kan 
word. Deur te gee, dui die kerk simbolies aan dat daar 'n interafhanklikheid bestaan. Deur saam te vier, dui die kerk die mede-afhanklikheid voor die Transendente aan. Deur te gee, dui die kerk solidariteit met die nood van die ontvanger aan.

Wanneer die kerk gee, geskied dit op dieselfde kontinuum van 'n God wat alles vir die wêreld feil het, 'n God wat Homself onvoorwaardelik vir die wêreld gee. Die rede waarom die kerk gee (hetsy deur diakonale versorging of deur die verkondiging van die evangelie), is omdat die kerk erken dat die kerk so baie ontvang het. Die kerk funksioneer anti-utilitaristies: Daar is geen verwagting van 'n wederkerige teenprestasie wat die kerk handig te pas sal kom nie. Die kerk gee as voortsetting van die voorbeeld wat die onselfsugtige God kom stel het deur te gee, sonder om iets in ruil te verwag.

\section{Erkenning Mededingende belange}

Die outeur verklaar dat hy geen finansiële of persoonlike verbintenis het met enige party wat hom nadelig kon beïnloed in die skryf van hierdie artikel.

\section{Literatuurverwysing}

Bosch, D., 2011, Transforming mission: Paradigm shift in theology of mission, 20th anniversary edn., Orbis Books, New York.

Caillé, A., n.d., Anti-utilitarianism, economics and the gift-paradigm, viewed 30 April 2012, from www.revuedumauss.com.fr/media/ACstake.pdf

Mauss, M., 1990, The gift: The form and reason for exchange in archaic societies, transl. W.D. Halls, WW Norton, New York.

Moltmann, J., 1984, Diakonie im Horizont des Reiches Gottes: Schritte zum Diakonentum aller Gläubigen, Neukirchener Verlag, Neukirchen.

Noordegraaf, A., 1991, Oriëntatie in het Diakonaat, Uitgeverij Boekencentrum, Zoetermeer.

Sundermeier, T., 1995, Konvivenz und Differenz, Verlag der Evangelische-Lutherse Mission, Erlangen. 